УДК 550.34

DOI: $10.23671 /$ NNC.2015.3.55283

\title{
COMPLEX ASSESSMENT OF SOIL MODEL IN URBAN AREA
}

\author{
(C) 2015 R.R. Durgaryan', M.A. Avanesyan', S.H. Babayan', M.R. Gevorgyan', \\ H.Y Babayan', A.R. Arakelyan ${ }^{2}$
}

${ }^{1}$ Institute of Geological Sciencies NAS RA (IGS NAS RA), Republic of Armenia, Yerevan 0019, Marshal Baghramyan ave. 24a, e-mail: raffie_d@yahoo.com;

${ }^{2}$ Armenian Association of Seismology and Physics of the Earth (AASPE), Republic of Armenia, Yerevan 0038, Shinararneri str. 10, e-mail: vitoarakel@yahoo.com

The main goal of the study is to numerically model the effects of local soil conditions in sedimentary basins. Taking into consideration other impacts, such as geological situation and structure, underground water level, man-made effects on ground condition, secondary geological effects, etc. we are generally focused on complex analyses of ground condition. For this case we have involved and collected a dense set of in-situ seismic measurements in Gyumri-city to supplement existing knowledge. We have used this dataset to study the spatial correlation structure of S-wave velocities and microtremor predominant frequencies in Gyumri-city part of Shirak sedimentary basin. The average characteristic velocity value of $310 \mathrm{~m} / \mathrm{s}$ and predominant periods of natural vibrations of soils ( $\mathrm{F} 0<1(0,45 \mathrm{~Hz}$ on average) and $5<\mathrm{F} 1<10(7 \mathrm{~Hz}$ on average) $)$ was calculated based on the models of propagation of surface waves and microtremors in GyumriCity master plan area.

Keywords: microtremor, S-waves, MASW, characteristic velocity, predominant period.

\section{Introduction}

It is common knowledge that the Republic of Armenia, and the Gyumri-city, in particular, is located within a seismically active zone. Within such zones, periodically recurring strong earthquakes of varying size (magnitudes) can produce strong ground motions, which may cause increased seismic impacts in the upper strata of the Earth crust. The problem becomes more urgent if there is a case of multiple layers, bedded in versatile layering, and severely inhomogeneous environments. In the meantime, seismic impacts in soft soils can be times stronger than in rocky soils.

In general, information on seismic effects within the upper section of the Earth crust (30 meters) determined by these and other natural and man-made conditions is presented in detail in the Building Code [Хачиян и др., 2006] according to soil classification and seismic zones (baseline value of seismic hazard).

As part of the entire set of investigations, works implemented in this direction were aimed

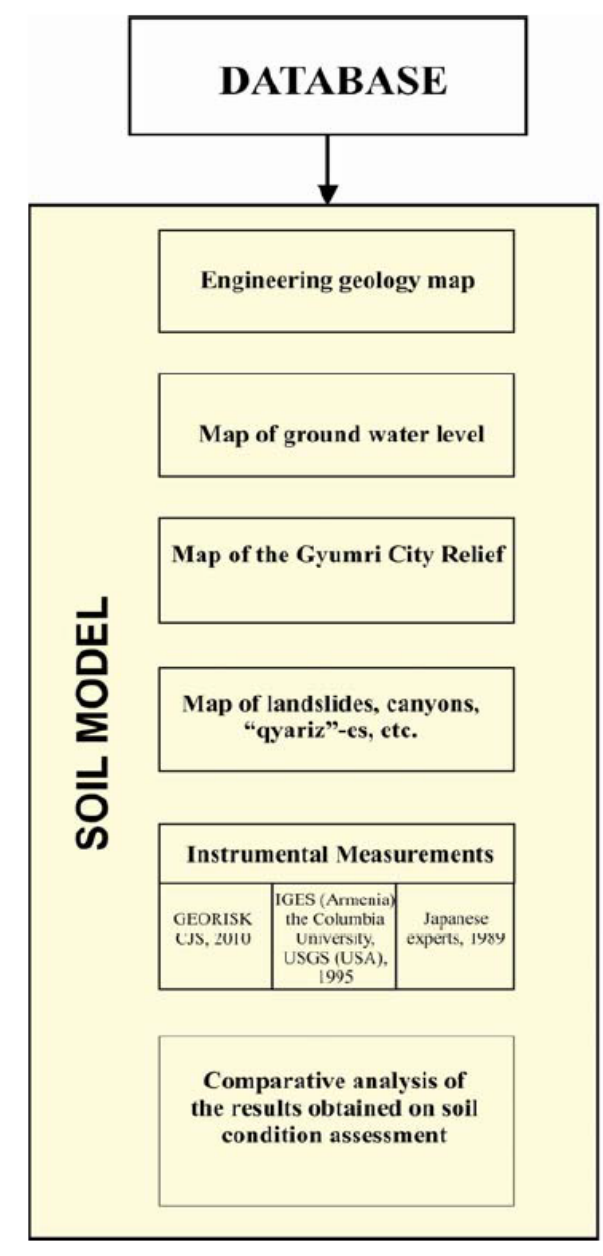

Fig. 1. The strategy of the analysis of soil conditions in Gyumri-city 


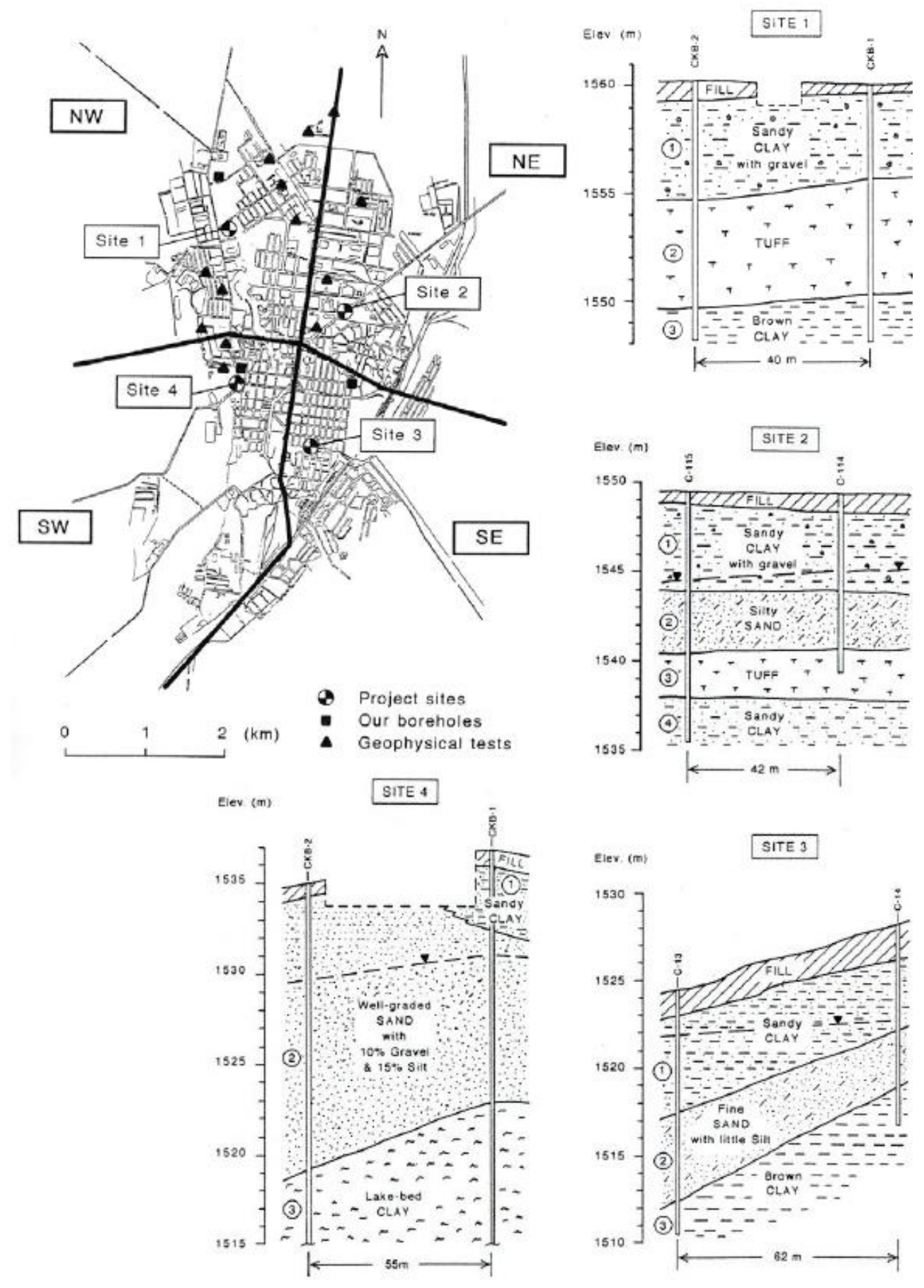

Fig. 2. Geotechnical cross-sections for the four project sites in Gyumri (Yegian, 1992)

at evaluation of seismic hazard for the master plan of the Gyumri-city, accounting for local soil conditions, which would provide sound basis for the activities on seismic risk assessment. To ensure comprehensive and impartial assessment of local soil conditions, we took into account and considered the following databases and work stages (fig. 1).

\section{Geology of the Gyumri-city area}

The Shirak depression is a typical intermountain trough with flat bottom, filled with Quaternary lacustrine, lake-and-alluvial and alluvial sediments that overlie the Akchaghil 
dolerites, basaltic andesites, various horizons of strongly dislocated deposits of the Miocene, Oligocene, Eocene, Cretaceous and Jurassic. The Shirak Plain and the Akhourian River valley stand out clearly there. The Shirak Plain represents the surface of the same-name depression built with the Early-Middle Pleistocene sediments of Lake Shirak. [Sayadyan, 2009]. Geological structure of the Shirak Depression was studied by many researchers in detail. In particular, Paffenholtz K.N. [Paffenholtz, 1964] described the lithological stratigraphic section of the depression in the following way (top to bottom):

1. Alluvial and proluvial formations up to $7,5 \mathrm{~m}$ thick;

2. Volcanic tuff of dark color up to $12 \mathrm{~m}$ thick;

3. Old alluvial-proluvial sediments (pebblestone, clay, sands) up to $35 \mathrm{~m}$ thick;

4. Typical lake sediments represented by clays (sandy in places) with inclusions of pebble, inter-layers of volcanic sand in the form of lenses, diatomite clays and tuff limestones. The overall thickness of the stratum is $250 \mathrm{~m}$.

\section{Engineering geology}

From the standpoint of engineering geology, presence of this kind of clayey and sandy-clay unconsolidated and highly plastic sediments, "sandwich"-type inter-layering of strata that have different physical and mechanical properties (fig. 2), as well as the high level of ground water are among the main factors of the disastrous effect seismic impacts can have within the Gyumri-city area, which was demonstrated during both the Spitak earthquake of 1988, and the earthquake of 1926.

Many studies have mentioned the contribution of unfavorable soil conditions and amplification of the seismic effect during the Spitak earthquake [Borcherdt et al., 1989; Yeghian, Ghahraman, 1992; Бабаян, 2001; Хачиян и др., 2006].

\section{Hydro-geological conditions}

1. There are two main horizons of ground waters within the Gyumri-city area - the supra-tuff and sub-tuff horizons. These waters pour out within the central part of the city at the sites, where tuffs, serving as the confining bed for the supra-tuff water, are common. Large portion of surface and atmospheric water penetrates into the sub-tuff strata of sandy-clayey and pebble-gravely soils, forming a sub-tuff water horizon, for which lake clays serve as the confining bed. This horizon is up to $15 \mathrm{~m}$ thick and is intensively drained within the valleys of the Akhourian River, Gyumri River and Cherkezi-Dzor River. This water horizon feeds also springs and marshes in the city stadium district and the Cherkezi-Dzor, as well as the swamps located in the southern area of the city [Бабаян, 2001; Генеральный план г. Гюмри, 2001].

\section{Landslide processes and dangerous man-made effects in the area of the Gyumri city}

The main landslide effects - soil subsidence and rock falls - are common also over the valley of the Cherkezi-Dzor River, displaying thicknesses of up to $25 \mathrm{~m}$, and vertical displacements of up to 20 meters. Some of the landslides are in relatively stable condition, but if water is present, the hazard of landslide activation builds up. Moreover, over-loading of the slopes, construction activities, agricultural use of the land on the slopes and their undercutting activate landslide processes sharply (fig. 3).

Along with landslides, such effects as rock collapses, falls, soil subsidence and other are observed as well. Landslide effects developed mostly in the areas of so-called Arapi 


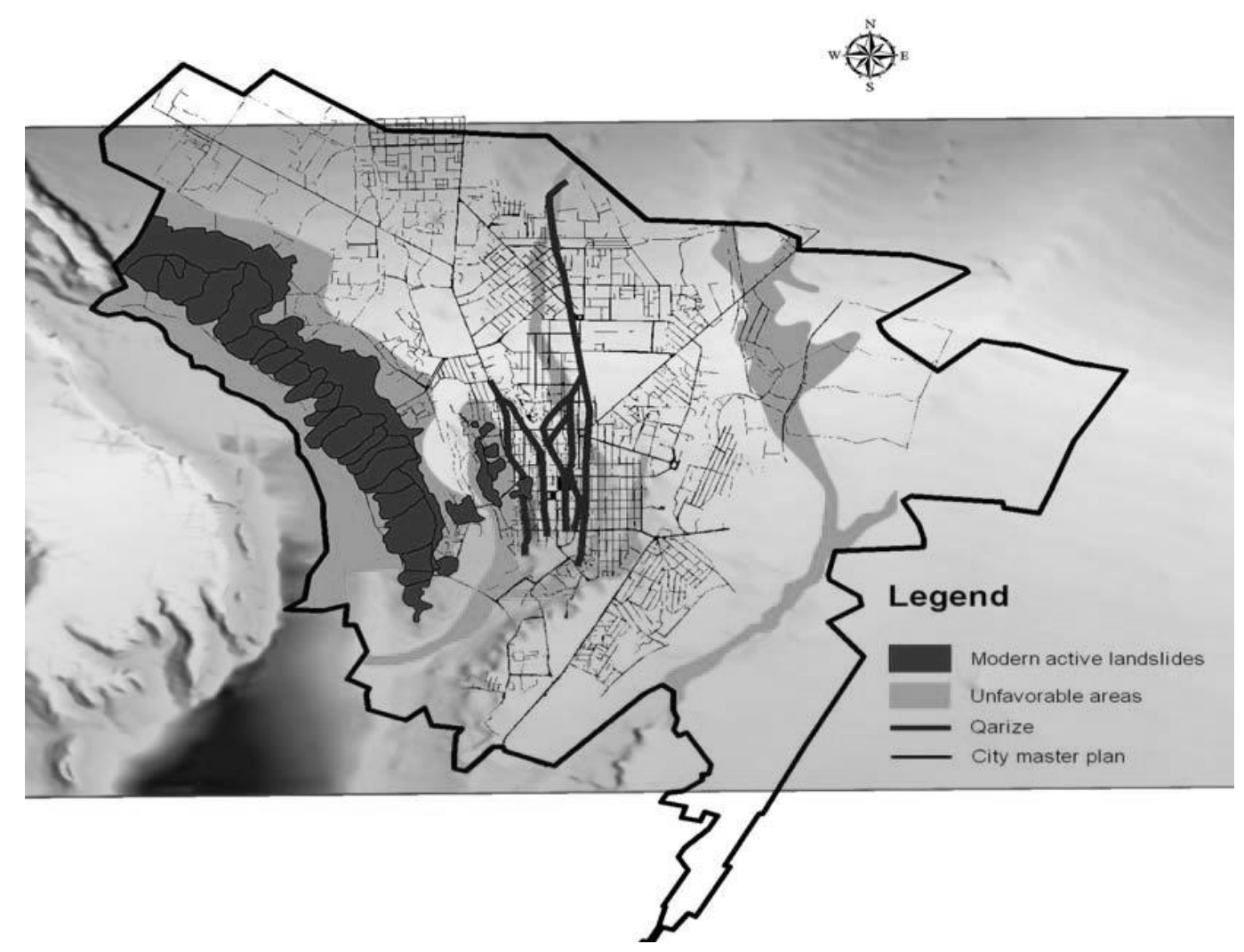

Fig. 3. Map of distribution of landslides and hazardous man-made /anthropogenic/ effects within the area of Gyumri City

Suite, represented by lacustrine-river deposits, pebble, sands, plastic clays, loams and diatomite clays of Middle-Quaternary age. At some sites, landslide phenomena involve also ignimbrite tuffs of the Yerevan-Leninakan type, overlying the lake and fluvial sediments. In the majority of cases, these processes are represented by regressive block-type or flowtype landslides when displacement develops regressively (landslide head part spreads gradually upwards on the slope).

Landslide effects have activated drastically after the Spitak earthquake as it had triggered activation of more or less stabilized sites. The uncontrolled land use within these areas, construction and slope loading with various structures, slope undercutting, and the malfunctioning or complete unavailability of drainage systems to provide for surface and ground water run-off has led to a significant increase of the rate of activity of landslide processes and of the potential of development of new areas, where slope effects are manifested.

It is important to note that no engineering protection measures have been actually realized for these areas during the last years. In addition to the listed effects, underground processes related to natural and man-made voids have been observed in Gyumri, in particular, in the central district of the city [Бабаян, 2001]. Periodically, these underground discontinuities manifest themselves in deformation, settlement and destruction of buildings in some parts of the city. The results of geophysical surveys indicate that the area of Gyumri is characterized by very complex and tangled network of the underground infrastructure, the greater part of which corresponds to qyarizes (qavriz, kanat, qanqan and other) [Гаспарян Р.К., Гаспарян В.Р., 2009]. 


\section{Analysis of the preceding geophysical studies of soils completed for the areas of Gyumri-city and Shirak Depression}

The first map of seismic micro-zoning (SMZ) of Gyumri-city area prepared by the Institute of Geophysics and Engineering Seismology (IGES) of the NAS of RA in 1971 was tested by the earthquake of 1988. Detailed study of the Spitak earthquake of 1988 has demonstrated that complex structure of the Shirak Depression determined sharp increase of earthquake intensity, velocities and duration of seismic shakings, which led to large casualties and high-rate destruction in Gyumri. Apart from this, it is necessary to consider not only the first tens of meters, but also the deeper strata [Халтурин и др., 1997].

From the standpoint of seismic hazard assessment in seismically active regions it is extremely important to study local soil conditions ("site effect"). Depressions of similar structure in San-Francisco, Mexico, and elsewhere have been studied during many years to assess this kind of effects during earthquakes. Among empirical methods, the most common is the H/V approach known also as the Nakamura method [Nakamura, 1989]. This method was for the first time proposed by Nogoshi and Igarashi [Nogoshi, Igarashi, 1971] that had based on the preliminary studies by Kanai and Tanaka [Kanai, Tanaka, 1961]. Similar measurements were made also by the Japanese specialists in Gyumri-city area directly after the Spitak earthquake of 1988.

According to the findings of the conducted studies, soil vibration predominant periods for the central part of Gyumri fall in the range of 0,51-0,64 s (1,5-2,0 Hz) [Khachian, 2008; Suyehiro et al., 1989], and 0,6-0,8 s (1,25-1,6 Hz) [Eisenberg, 1989], while during aftershocks these were $0,2-2,5 \mathrm{~Hz}(0,4-5 \mathrm{~s})$ [Borcherdt et al., 1989]. The joint study conducted by the Columbia University, United States Geological Survey (USGS), and the Institute of Geophysics and Engineering Seismology (IGES of the NAS of RA) in 1994 applied the Nakamura method and measured soil vibration spectra, with predominant periods of $2 \mathrm{~s}(0,5 \mathrm{~Hz})$ [Field et al., 1995]. Out of the four measurement sites, Point AGA was the only one located on bedrock, while Points LMD, MAR and SLO were measured within the Shirak Depression.

In 2001, IGES of the NAS of RA prepared the map of seismic micro-zoning of Gyumri-city area where engineering geology, hydrogeology, seismic prospecting and other types of data were used. This map served as the basis for the master plan of Gyumri, it identified zones with different values of peak ground acceleration $(0,28 \mathrm{~g}-0,56 \mathrm{~g})$ [«ArmProyekt», 2001]. That map (prepared at the scale of 1:10 000) passed through all required stages of getting concurrence, complex expert evaluation and approval, and represents the basic urban development document.

However, according to the new Building Code adopted in 2006 (CH PA II-6.02-2006) Gyumri-city falls into Seismic Zone 3 with estimated seismic hazard level of 0,4g. In 2010, the new concept of seismic safety development adopted in the Republic of Armenia set forth the requirements with respect to application of new approaches and techniques, which necessitated revision of seismic hazard assessment studies.

In 2010, in the framework of this Project, GEORISK Scientific Research CJS conducted new geophysical surveys aimed to revealing dynamic characteristics of soils within the limits of Gyumri-city, considering the requirements of the above legislative acts and norms, as well as the results of earlier studies, and international standards. 


\section{Analysis of the obtained results and dynamic characteristics of soils and soil model}

Considering dense network of urban development in Gyumri, military and industrial facilities, and other infrastructure available in the city, the Contractor (GEORISK CJS) assessed the situation and found it appropriate to realize geophysical surveys using a multi-channel seismic station (36 observation points) and the method of micro-tremor records (50 observation points) to enable determination of soils' seismic properties (shear wave propagation velocities, natural periods of soil vibration) within the upper 30 meters section and establishing soil categories (fig. 4). To record seismic waves, vertical seismic sensors with natural vibration period of $4,5 \mathrm{~Hz}$ were used. The method of multi-channel analysis of surface waves (MASW) was applied [Nazarian et al., 1983].

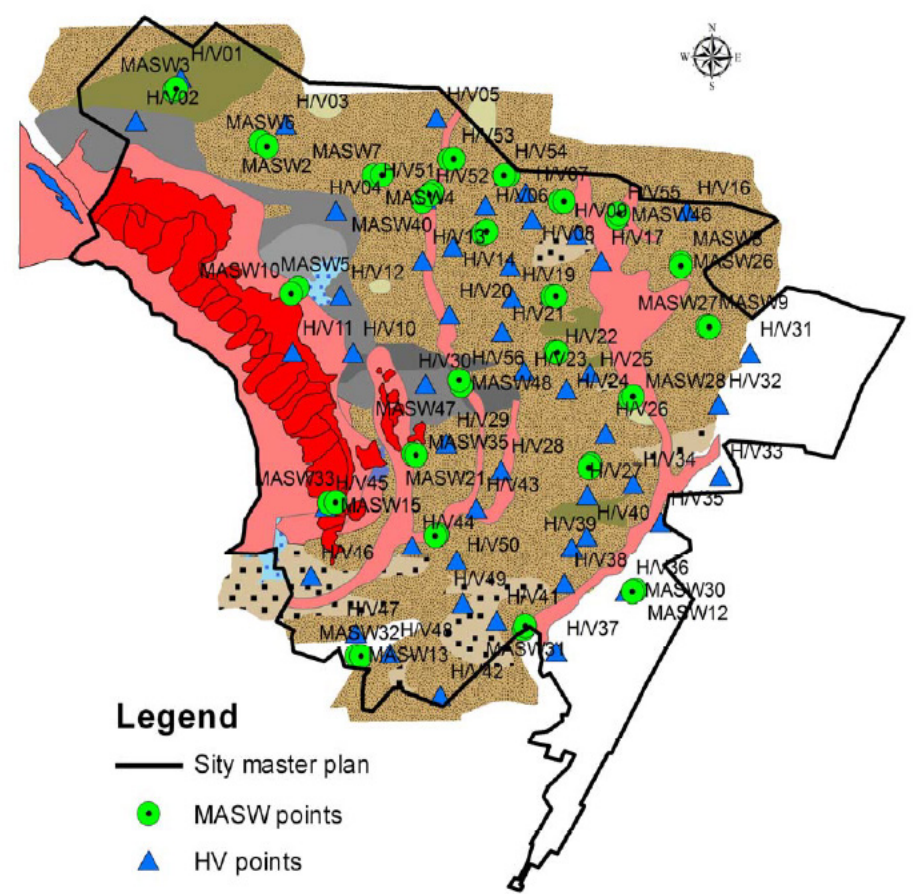

Fig. 4. Locations of geophysical record points (GEORISK-2010) on the map of engineering geology conditions within the area of the master plan of Gyumri-city

In compliance with Subclause 5.3.3, Clause 5,3 of the RA Building Code II - $6.02-$ 2006 , the average $V_{S}$ value of shear wave propagation velocity and the value of predominant $\mathrm{T}_{0}$ period for a soil, in case of heterogeneous soil section, are determined theoretically or by testing during engineering-geology surveys and seismological investigations, and values of $\mathrm{V}_{\mathrm{S}} / 1,3$ and 1,3 $\mathrm{T}_{0}$ are applied as their estimated values [Хачиян и др., 2006].

In terms of geology, the upper $6 \mathrm{~m}$-deep layer corresponds to sands and loamy sands, including the soil and vegetation layer, and the second layer includes tuff and has the depth of $6 \mathrm{~m}$. According to the observations made by GEORISK CJS in 2010, these layers are immediately underlain with sands, loamy sands and plastic clays (fig. 5). The latter can be up to $120 \mathrm{~m}$ thick, as attested by the integral analysis of the relevant frequencies of microtremors and shear wave propagation results.

As an outcome of the integral analysis of all collected data, the map of the distribution of average shear wave propagation velocities over the area of the Gyumri-city master plan (general plan) was prepared (fig. 6). 


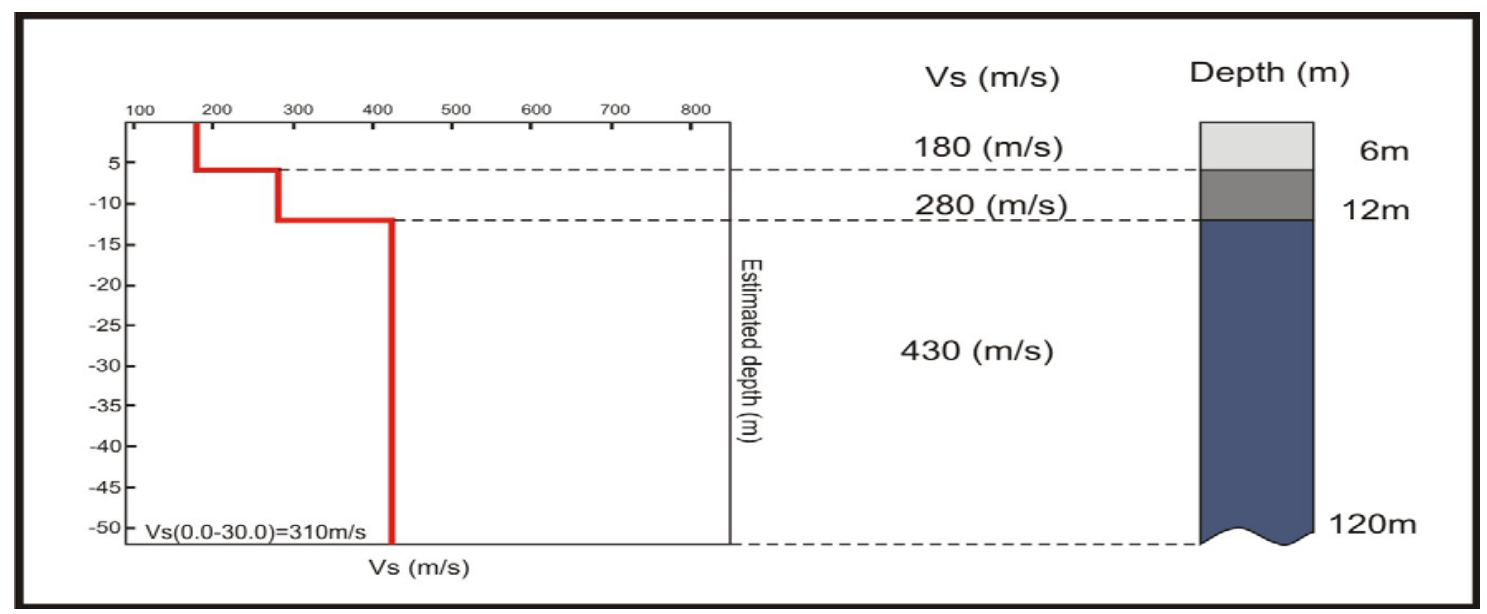

Fig. 5. Model of average velocities of shear wave distribution

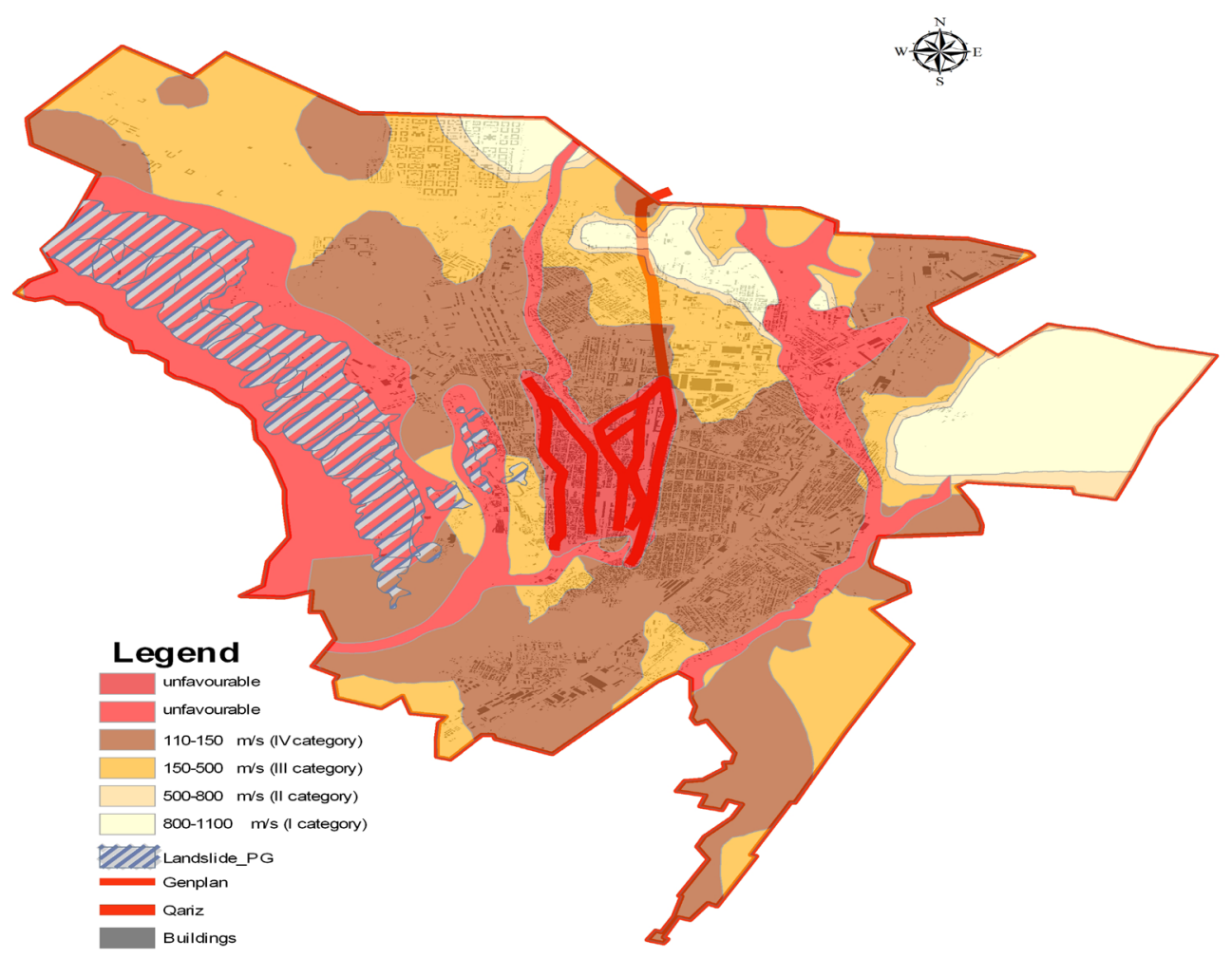

Fig. 6. The map of $V_{S 30}$ velocity distribution superimposed with the map of qyarizes, gullies and landslide effects

Considerable share of damages caused by destructive earthquakes worldwide is related to the amplification of seismic waves in the near-surface layers of the Earth crust, which is determined by local soil conditions. Recognizing the above, we conclude that from the standpoint of seismic hazard assessment for seismically active regions, it is extremely important to study local soil conditions. For this purpose, a series of investigations should be carried out. Among of the empirical methods, most common is the $\mathrm{H} / \mathrm{V}$ method, known also as the Nakamura method. A few studies carried out based on the spectral ratios of microtremors [Nakamura, 1989; Tenorio, 1997] for hard soils and bedrocks have demonstrated the credibility of these statements [SESAME, 2004]. 
Site effects associated with local geological conditions are important part of any seismic hazard assessment. Many examples of disastrous earthquake consequences have demonstrated the importance of reliable analytical procedures and hazard calculation methods as well as risk mitigation strategy. In this regard, microtremor records with the $\mathrm{H} / \mathrm{V}$ processing technique, or the Nakamura's method, were proposed to help deriving characteristics of local soil conditions - the "site effect" (European research project SESAME). This method proved to be the most efficient in assessment of natural vibration predominant periods of Quaternary sediments. The curves of predominant soil vibration periods shown in fig. $7 \mathrm{a}$ and $7 \mathrm{~b}$ have high rate of matching and reflect predominant periods of natural vibrations of the sedimentary basin and surface layers.
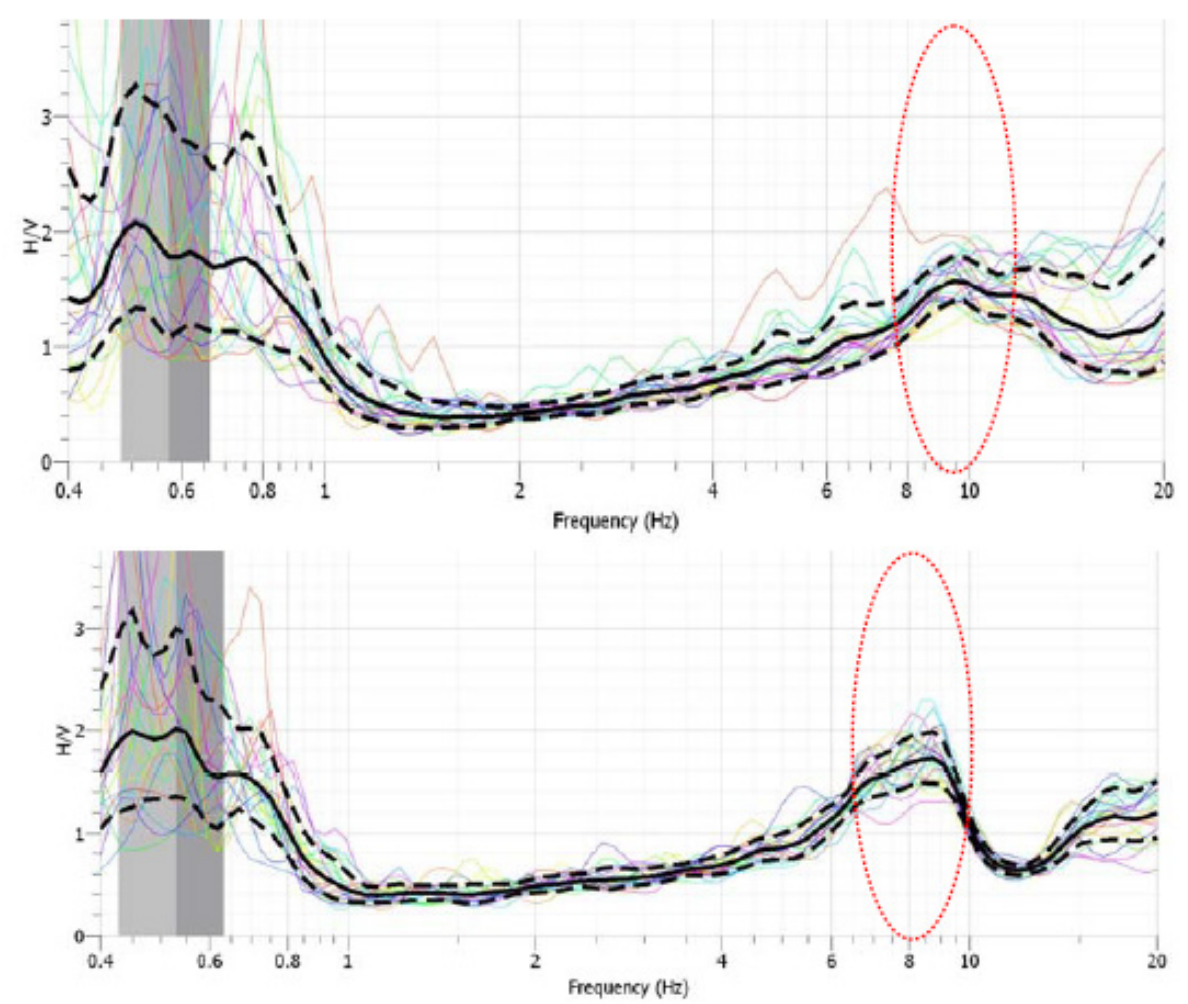

Fig. 7(ab). Characteristic curves of natural vibrations for the soils in Gyumri-city (GEORISK 2010)

According to the recommendations of the SESAME Project and the presented consensus results achieved by participants of the European Research Project based on the comprehensive and detailed investigation, the spectral ratios derived by us are characteristic for thick (up to $800 \mathrm{~m}$ ) sedimentary basins, to which lake-fluvial and lake sediments correspond. Based on this example, predominant period $\mathrm{F} 0<1(\mathrm{~Hz})$ corresponds to natural vibrations of a basin, while $\mathrm{F} 1 \approx 10(\mathrm{~Hz})$ reflects vibrations of the surface layer. In addition to the dynamic properties of soils, the performed works allowed us applying overall analysis of geological and geophysical data to build the model of surface wave propagation average velocities for the Gyumri-city area.

\section{Conclusions}

1. From the standpoint of seismic hazard assessment for seismically active regions, it is extremely important to study local soil conditions (site effect), and it is necessary 
to take into account dynamic characteristics of not only the first tens of meters, but also those of deeper layers.

2. The predominant periods of natural vibrations of soils according to the BCRA 2006 document fall in the range of $0,1-3,33 \mathrm{~s}(0,3-10 \mathrm{~Hz})$, with two distinct sub-ranges of $\mathrm{F} 0<1$ $(0,45 \mathrm{~Hz}$ on average) and $5<\mathrm{F} 1<10(7 \mathrm{~Hz}$ on average $)$.

3 . In compliance with the European research project SESAME and worldwide experience, $\mathrm{F} 0 \approx 0,45 \mathrm{~Hz}$ corresponds to the natural vibrations of a sedimentary basin, and $\mathrm{F} 1 \approx 7,0(\mathrm{~Hz})$ is typical for surface layer vibrations.

4. The results of processing of surface wave measurements demonstrated that velocities of shear wave propagation $\left(\mathrm{V}_{\mathrm{S} 30}\right)$ fall in the range of $150-400 \mathrm{~m} / \mathrm{s}(110-310 \mathrm{~m} / \mathrm{s}$ with allowance for the BCRA 2006).

5 . The average characteristic velocity value of $310 \mathrm{~m} / \mathrm{s}$ was calculated based on the models of propagation of shear waves within the upper $30 \mathrm{~m}$ section in Gyumri-city.

\section{References}

1. Borcherdt R.D., Glassmoyer G., Andrews M., and Cranswick, E. (1989). Effect of site conditions on ground motion and damage, in Armenia earthquake reconnaissance report, Earthquake Spectra, 5, 23-42.

2. Eisenberg Y.M. Spectra and damages of the Spitak earthquake. Spitak-88. Proceeding of International Seminar on Spitak -88 Earthquake, Sponsored by UNESCO, Yerevan, May 23-26, 1989, pp. 291-301.

3. Field E.H., Clement A.C., Jacob K.H., Aharonian V., Hough S.E., Friberg P.A., Babaian T.O., Karapetian S.S., Hovanessian S.M, and Abramian H.A. Earthquake Site-Response Study in Giumri (Formerly Leninakan), Armenia, Using Ambient Noise Observations, Bulletin of the Seismological Society of America, Vol. 85, No. 1, pp. 349353, February 1995.

4. Kanai K., Tanaka T. 1961. On Microtremors. VIII.-Bull. of the Earthquake Research Institute, 39, 97.

5. Nakamura Y. (1989). A method for dynamic characteristics estimation of subsurface using microtremor on the ground surface, Quaterly Report of the Railway Technology Research Institute, 30, 25-30.

6. Nazarian S., Stokoe, K.H., and Hudson, W.R. (1983) Use of spectral analysis of surface waves method for determination of module and thicknesses of pavement systems: Transportation Research Record, 930, 38-45.

7. Nogoshi M., Igarashi T. 1971. On the amplitude characteristics of microtremor (part 2). Jour. Seism. Soc. Japan, 24, 26-40.

8. Paffenholtz K.N. Geology of Armenian SSR, II-Stratigraphy. Pub. Arm. Nat. Science. Acad. 1964

9. Sayadyan Yu. The newest geological history of Armenia. Academy National of Sciences of Armenia Pub. "Gitutyun”. Yerevan 2009

10. SESAME, (2004), Guidelines for the implementation of the H/V spectral ratio technique on ambient vibrations. Measurements, processing and interpretation, European Commission - Research General Directorate Project No.EVG1-CT-2000-00026 SESAME, report D23.

11. Suyehiro S., Okada T., Kobayashi H., Hirosawa M., Murakami M., Sugano S. Evaluation of the Results obtained by the Japanese Mission of Armenia. Proceeding of international Seminar on Spitak-88 Earthquake, Sponsored by UNESCO, Yerevan, May 23-26, 1989, pp. 87-106. 
12. Tenorio C. Site Response evaluation: A review of the problems involved, estimation techniques and Nakamuras single station method, and Shallow crustal structure in Guatemala using P- and S-wave inversion,, Unpublished Master Thesis, Department of solid Earth Physics. University of Bergen, 1997 p.

13. Yeghian M., Ghahraman V. The Armenia earthquake of December 1988, Northeastern University, Boston Massachusetts, October 1992.

14. Бабаян Т.О. Сейсмическое микрорайонирование территории города Гюмри. Научно-технический отчет. ИГИС НАН РА, Гюмри, 1977 г. и 2001 г.

15.Гаспарян Р.К., Гаспарян В.Р. Подземные пустоты как факторы обострения геоэкологических условий г. Гюмри, Сборник научных трудов конференции, посвященной 20-летию Спитакского землетрясения. Гюмри. 2009 г., с. 135-141.

16. Генеральный план г. Гюмри. «Армпроект», Ереван, 2001г. (на арм. яз.).

17. Халтурин В., Такер Б., Двелли Л. (1997) Землетрясение неизбежно. Stanford, GeoHazard. C.17.

18. ХачиянЭ.Е., Маркарян Т.Г.,Амбарцумян В.А. “Сейсмостойкоестроительство. Нормы проектирования”. CHPA II-6.02-2006. Ереван 2006 [Khachiyan E.E., Markaryan, T.G., and Hambartsoumyan, V.A., 2006. Earthquake Engineering: Design Norms, CHPA II-6.02-2006].

DOI: 10.23671/VNC.2015.3.55283

\title{
КОМПЛЕКСНАЯ ОЦЕНКА МОДЕЛИ ГРУНТОВ НА ТЕРРИТОРИИ ГОРОДА
}

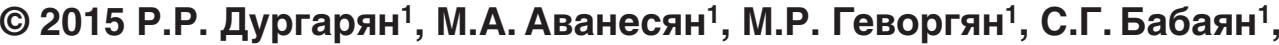 \\ Г.Е. Бабаян ${ }^{1}$, А.P. Аракелян ${ }^{2}$
}

${ }^{1}$ Институт геологических наук НАН РА (ИГН НАН РА), Республика Армения, 0019, Ереван, пр. Маршала Баграмяна, 24a, e-mail: raffie_d@yahoo.com;

${ }^{2}$ Армянская ассоциация сейсмологии и фризики Земли (ААСФЗ), Республика Армения, 0038, Ереван, ул. Шинарарнери 10, e-mail: vitoarakel@yahoo.com

Основной целью данного исследования является моделирование влияния локальных грунтовых условий в пределах осадочных бассейнов. Принимая во внимание такие влияния, как геологические условия и строение, уровень грунтовых вод, влияние человеческой деятельности на грунтовые условия, вторичные геологические эфрфекты и т.д. мы, в основном, сосредоточились на комплексном анализе грунтовых условий. Для этого были использованы данные плотной сети измерений на территории Гюмри в дополнение к существующим данным. Эти данные были использованы для изучения пространственной корреляции структуры скоростей S-волн и преобладающих периодов микротреморов в Гюмрийской части Ширакского осадочного бассейна. На основе моделей распространения поверхностных волн и микротреморов в пределах генерального плана г. Гюмри были получены: средняя характеристическая скорость, равная $310 \mathrm{~m} / \mathrm{c}$, и преобладающие периоды собственных колебаний грунтов (F0<1 (в среднем 0,45 Гц) и $5<\mathrm{F} 1<10$ (в среднем 7Гц)).

Ключевые слова: микротреморы, S-волны, MASW, характеристическая скорость, преобладающий период. 